\title{
Academic Resilience and Relationship with Meaning of Life Among Koya University Students
}

\section{Bayar Mirza Aziz}

Department of Education and Psychology, Faculty of Education, Koya University, Koya, Kurdistan Region, Iraq.

E-mail: bayar.mirza@koyauniversity.org

\section{Khalid Ismail Mustafa}

Department of Education and Psychology, Faculty of Education, Koya University, Koya, Kurdistan Region, Iraq.

E-mail: khalid.ismail@koyauniversity.org

\begin{abstract}
:
This study aimed to find out the level of academic resilience (AR), meaning of life (MOL) and the relationship between them among students at Koya University. 740 samples were selected randomly. The researcher used two scales; one scale adapted academic resilience scale by Cassidy (2016), and meaning of life scale was developed by the researchers. Principle Component Analysis (PCA) was conducted to test the validity of the meaning of life items. The validity and reliability of the instruments were at convinced level. The result showed that the students have a low level of academic resilience and a high level of meaning of life; the result showed a statistically positive relationship between academic resilience and meaning of life, also the result showed that the academic resilience was predicted meaning of life.
\end{abstract}

Keywords: Academic Resilience, Meaning of Life, University Students. 


\section{Introduction:}

Education is a process of gaining information that leads to a prosperous future which is clear and known, resilience refers to the ability that allows people to overcome difficult life events successfully and gain competence or skills from the process of overcoming challenges and adversity (Chung, 2008). In addition, resilience is a dynamic process whereby when people experience difficulties, they show adaptive behaviors. Despite the fact that students experience the same challenging or threatening situations, those who are academically resilient have ability to change stressful circumstance to personal growth and benefit (Santhosh and James, 2013).

In his theory Bonnie Benard proposes three protective factors that together increase resilience in students, including caring relationships (Benard, 2004). Hobfool in his theory states that (self-efficacy, self- esteem, resilience, motivation and optimism) are personal resource (Hobfoll, 1989). In addition, based on Ecological development theory an individual's development happens in different settings and in interaction with others such as social relationships (Bronfenbrenner, 1979).

According to previous studies by Hatice Tambag and Rana Can (2018) undergraduate students have a low level of academic resilience. Howerver, Coşkun, Garipağaoğlu and Tosun (2014) found that undergraduate students have high resiliency level. Mwangi and Ireri (2017) indicate that there were more girls with high level of academic resilience compared to boys. Panchal, Mukherjee and Kumar (2016) concluded that there are positive significances between resilience and optimism. Rudwan and Alhashimia (2018) found that there are positive associations between resilience and mental health. Also, coping styles and personality traits are predictors of academic resilience (Tamannaeifar and Shahmirzaei, 2019). In addition, Muangi, Ireri and Muaniki (2017) showed that the external and internal protective factors jointly predict academic resilience.

"Meaning of life is a reason for living and trying to comprehend how important life is by experiencing or feeling it" (Tas and İskender, 2018.,p21). Steger, et al (2008) described the search of meaning in life as the power, intensity, and activity of the desire and efforts of people to establish or increase their understanding of their life's meaning, significance, and purpose. Furthermore, meaning in life is the capacity of a person to understand his/ her life, such as knowing oneself and the outside world and adapting to it (Steger and Frazier, 2005).

The construction of meaning of life was first introduced by Victor Frankl. Frankl in (1965) thought that the three classes of such values are described: creative, experiential, and attitudinal. By the act of making or manufacturing something, creative values are actualized. When people write a script, sketch an image, build a house, or give birth to a child, they instantiate creative values (Cited in Corey, 2004). In addition, Frankl used the word responsibility, when people understand that they are alone and have the ability to add meaning into their lives, as a result, seek goals that allow them to do so, people live responsibly. If they do not set and execute those targets, they are predisposed to depression and anxiety (Frankl, 1992).

Mohamad, AbdRazak, Mutiu (2011) showed that the postgraduate students perceive life to be meaningful. AlTarawneh et al, (2019) found that meaning in life is positively associated with psychological happiness among students. According to Karaman, Vela and Garcia (2020) there is a positive correlation between meaning of life 
and hope and life satisfaction, and they found that hope was moderately correlated with resilience and meaning of life. Sab and Ghomian (2019) showed that spirituality, and positive effect could predict a meaning of life. Garrison and Lee (2017) found that there is a positive association between search for meaning in life and presence of meaning in life among students. However, this study tries to examine the relationship between academic resilience and meaning of life and attempts to investigate the level of students' academic resilience, and the meaning of life.

\section{This present study aims to answer the following research questions:}

1- What is the level of academic resilience among Koya university students?

2- What is the level of meaning of life among Koya University students?

3- Is there any significant relationship between academic resilience and the meaning of life among Koya university students?

4- Is there prediction of academic resilience based on the meaning of life?

\section{Research design}

The study adapts a quantitative- survey method.

\section{Limitation of the study}

It consists of all students (morning study) at Koya University for the academic year (2020-2021).

\section{Materials and Method}

\section{Research population}

The population of this research includes all of the undergraduate students at Koya University in morning study which includes four faculties: Faculty of Engineering, Faculty of Science and Health, Faculty of Humanity and Social Science, and Faculty of Education. Also the two schools: School of Medicine and School of Physical Education. The total number of students is 3053 with 1387 students belong to Science Departments and 1666 Students belong to Social Science Departments in the academic year (2020-2021). 


\section{Sample Size}

The sample of this study consists of (740) students at koya University selected by using stratified random sampling procedure in the academic year (2019-2020), as shown in the table (1).

Table 1: The Pilot Study and Final Study Sample

\begin{tabular}{lll}
\hline & Pilot study & Final \\
\hline Meaning of life & 250 & \\
Academic resilience & 90 & 400 \\
\hline
\end{tabular}

\section{Research Instruments}

In this study, two questionnaires were used. The first one adapted academic resilience scale (ARS) which was designed by (Cassidy, 2016). This measure was used among undergraduate university students, which includes (30) items, it has 5-point likert from likely (1) to unlikely (5).

The second questionnaire was developed by the researcher in order to measure meaning of life in Koya University students', the researchers have used an open-ended questionnaire for making a new scale for meaning of life, the questionnaire distributed on (17) student's at Koya University, the open-ended questionnaire contained three questions. The research utilized established literature such as (Steger, et al., 2006; Hill, et al., 2018; Scheier, et al., 2006; Damasio, Hauck-Filho and Koller, 2016; Schuienberg, Schnetzer and Buchanan, 2011). Meaning of life questionnaire was consisting of (30) items and three hypothesized dimensions to underlying the meaning of life, the first dimension represented search for meaning, while the second was presence of meaning and the third dimension presented meaningless, these studies guides and helps to develop the meaning of life instrument via modifying, changing and adding the items according to a panel experts recommendations, the items used option scale from 1 (strongly disagree) to 7 (strongly agree).

\section{Validity and Reliability of the Instruments Translation Validity}

Validity refers to "whether a measure is truthful or genuine and what it claims to measure" (Jackson. 2015, p.70). To find out back translation; first, an expert who was fluent in English translated the academic resilience. Secondly, the Kurdish version was back-translated by another expert without seeing the English text. Then, both English versions were compared by another expert. Finally, a psychological expert reviewed all items and found that the Kurdish translation is equal to the original English. The researchers have decided to apply the scale after all items were clear in meaning. 


\section{Face Validity}

After translating the academic resilience scale and obtaining translation validity, the scale was validated by a panel of (5) experts in the field of Psychology. The researcher responded to their opinions and has performed the needed editing or deleting in the light of their suggestions. After that, the last version of the scale was prepared. It consisted of (28) items, items (3 and 14) in factor 1, (8 and 9) in factor 2, (3, 4, 5, and 6) in factor 3 have changed, and items (11 in factor 1 and 1 in factor 3 ) have been omitted because the percentage of agreement by experts was (\%60). Finally, the percentage of face validity was (\%87).

The researchers presented the questionnaire to panel of experts to find out the content validity for the questionnaire, based on the suggestions and opinions of panel of experts the researchers conducted the following changes. The meaning of life questionnaire consisted of (30) items, the item numbers (9 in dimension of search for meaning, 2, 9, and 11 in dimension of presence of meaning and 2, 3, 4, 5, 6 in dimension of meaningless) were removed and item numbers (1in presence of meaning and 1in meaningless) were modified and four items were added ( 9 in dimension of search for meaning , 20 and 21 in dimension of importance, 24 in dimension of meaningless), as shown in the table (2), the final (25) items are retained.

Table 2: Item Numbers and Dimensions after Suggestions of Panel of Experts

\begin{tabular}{lll}
\hline Items & Dimensions & Suggestion of Panel of Experts \\
\hline $\mathbf{9}$ & Search for meaning & Removed \\
$\mathbf{2 , 9 , 1 1}$ & presence of meaning & \\
$\mathbf{2 , 3 , 4 , 5 , 6}$ & Meaninglessness & \\
$\mathbf{1}$ & Presence of meaning & Modified \\
$\mathbf{1}$ & Meaningless & \\
$\mathbf{9 , 2 0 , 2 1 , 2 4}$ & & Added \\
\hline
\end{tabular}

\section{Reliability}

The researchers used Cronbach's Alpha to get the reliability on the academic resilience scale. The alpha value of the scale was $0.66(n=90)$ which means that the scale is reliable for application (Ursachi, Horodnic and Zait, 2015). Table (3) shows the reliability of the scale with item numbers and number of participants.

For the meaning of life questionnaire, reliability for presence of meaning dimension was 0.86 , life meaningless dimension was 0.86 , importance of meaning dimension was 0.88 , and search of meaning dimension was 0.832 . The overall Cronbach's alpha for this questionnaire was $0.80(n=400)$ which means that the questionnaire is reliable for application. Table (4) shows the reliability of all dimensions of meaning of life with item numbers.

Table 3: Reliability Statistics for Academic Resilience (AR)

\begin{tabular}{|c|c|c|c|c|}
\hline Scale & $\begin{array}{l}\text { Cronbach's } \\
\text { Coefficient }\end{array}$ & Alpha & Number of Items & $\mathbf{N}$ \\
\hline AR & .66 & & 28 & 90 \\
\hline
\end{tabular}


Table 4: Reliability of all Dimensions of The Meaning of Life after Pilot Study

\begin{tabular}{llcc}
\hline Scale & Dimensions & $\begin{array}{c}\text { Valid } \\
\text { Items }\end{array}$ & $\begin{array}{c}\text { Cronbach's } \\
\text { Coefficient }\end{array}$ \\
\hline Meaning of life & Presence of meaning & 6 & .868 \\
& Life Meaningless & 5 & .867 \\
& Importance of meaning & 4 & .888 \\
& Search of meaning & 5 & .832 \\
Total & 4 Dimensions & 20 & .809 \\
\hline
\end{tabular}

\section{Results}

To answer the first research question which states: (What is the level of academic resilience among Koya University students?), descriptive statistics were conducted, for analyzing the level of academic resilience. The result revealed that $(\mathrm{M}=106.96, \mathrm{SD}=12.18), \mathrm{N}=400$, and transformed data (3.82), mean $(106,96)$ was divided on number of items (28). As shown in table (5).

Table 5: Mean and SD of Academic Resilience

\begin{tabular}{llll}
\hline & N & Mean & SD \\
\hline Academic Resilience & 400 & 106.96 & 12.18 \\
\hline
\end{tabular}

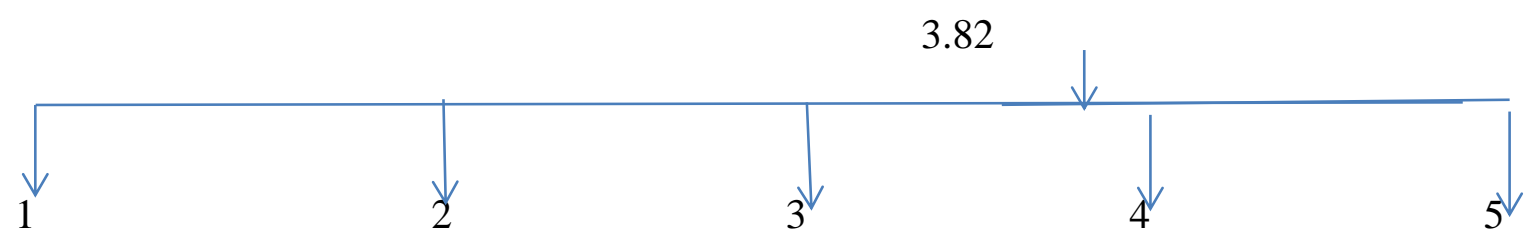

Number of Options of Academic Resilience

\begin{tabular}{ccccc}
\hline High possibility & Same possibility & Little possibility & Rarely possibility & No possibility \\
\hline 1 & 2 & 3 & 4 & 5 \\
\hline
\end{tabular}


The level of academic resilience was (Rarely possibility) which means that the students have a low level of academic resilience.

To answer the second research question which states: (What is the level of meaning of life among Koya University students?), descriptive statistics were conducted, for analyzing the level of meaning of life. The result revealed that $(\mathrm{M}=94.92, \mathrm{SD}=15.77), \mathrm{N}=400$, and transformed data (4.74), mean (94.92) was divided on number of items (20). As shown in table (6).

Table 6: Mean and SD of Meaning of Life

\begin{tabular}{llll}
\hline & N & Mean & SD \\
\hline Meaning of Life & 400 & 94.92 & 15.77 \\
\hline
\end{tabular}

\subsection{4}

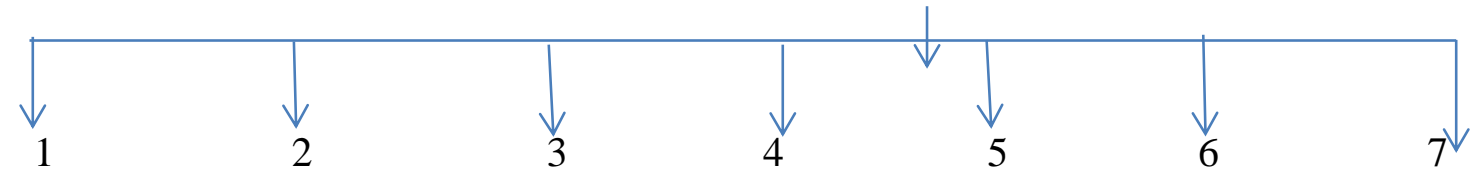

Number of Options of Meaning of Life

\begin{tabular}{ccccccc}
\hline $\begin{array}{l}\text { Totally } \\
\text { disagree }\end{array}$ & $\begin{array}{l}\text { Mostly } \\
\text { disagree }\end{array}$ & $\begin{array}{l}\text { Sometime } \\
\text { disagree }\end{array}$ & $\begin{array}{l}\text { Doesn't } \\
\text { matter } \\
\text { me }\end{array}$ & $\begin{array}{l}\text { Sometimes } \\
\text { agree }\end{array}$ & $\begin{array}{l}\text { Mostly } \\
\text { agree }\end{array}$ & $\begin{array}{l}\text { Totally } \\
\text { agree }\end{array}$ \\
\hline 1 & 2 & 3 & 4 & 5 & 6 & 7 \\
\hline
\end{tabular}

The level of meaning of life among students was (sometime I agree) which means the students have a strongly level in meaning of life.

To answer the third research question which states: (Is there any significant relationship between academic resilience and the meaning of life among Koya university students?), the relationship between academic resilience and meaning of life was determined based on (Spearman's correlation). Results revealed that there is a significant positive relationship between them $(\mathrm{r}=0.212, \mathrm{p}=0.001)$, (table 7$)$ illustrates the mean and standard deviation of academic resilience questionnaire, $(\mathrm{M}=106.96, \mathrm{SD}=12.18)$, and meaning of life questionnaire $(\mathrm{M}=94.92, \mathrm{SD}=15.77)$, with $(\mathrm{N}=400)$. 
Table 7: Correlation between academic resilience and meaning of life

\begin{tabular}{lcclll}
\hline & $\mathbf{N}$ & Mean & $\begin{array}{l}\text { Std. } \\
\text { deviation }\end{array}$ & $\begin{array}{l}\text { Spearman } \\
\text { correlation }\end{array}$ & $\begin{array}{l}\text { P-Value } \\
\text { (Sig.) }\end{array}$ \\
\hline Academic resilience & 400 & 106.96 & 12.18 & & \\
Meaning of life & 400 & 94.92 & 15.77 & $0.212^{* *}$ & 0.001
\end{tabular}

**. Correlation is significant at the 0.01 level (2-tailed).

To answer the fourth research question which states: (Is there prediction of academic resilience based on the meaning of life?), a regression analysis was conducted, to determine whether academic resilience predicted meaning of life. The predictor measure of academic resilience accounts for $2.5 \%$ of variance in meaning of life. The result indicated that $(\mathrm{R}=0.159, \mathrm{R}$ square $=0.025) . \mathrm{F}$ value is equal to 10.37 which is significant at level 0.001 . It may be interpreted that variable academic resilience appropriately predicts meaning of life. $(\mathrm{Y}=72.86+0.206$ $\mathrm{X})$. As shown in table (8).

Table 8: Regression Analysis (Dependent Variable: Meaning of Life

\begin{tabular}{llllllll}
\hline Model & Variable & R & $\begin{array}{l}\text { R } \\
\text { Square }\end{array}$ & $\begin{array}{l}\text { Adjusted } \\
\text { R square }\end{array}$ & $\begin{array}{l}\text { Std. Error of } \\
\text { the Estimate }\end{array}$ & $\begin{array}{l}\text { P- } \\
\text { Value } \\
\text { (Sig.) }\end{array}$ \\
\hline 1 & Resilience & 0.159 & 0.025 & 0.023 & 15.59 & 10.37 & 0.001 \\
\hline
\end{tabular}

\section{Discussion}

According to the first question of the research, (What is the level of academic resilience among Koya University students?). The result showed that the students have a low level in academic resilience. This finding is consistent with the previous literature results reported by (Hatice Tambag and Rana Can, 2018) who indicated that the undergraduate students have a low level of resilience in the field of health sciences. According to Coşkun, Garipağaoğlu and Tosun (2014) they are undergraduate students have high resiliency level. According to Mwangi and Ireri (2017) they are there were more girls with high level of academic resilience compared to boys. These level may be caused by a variety of factors: University environment, family, friends and low socioeconomic status, also some internal factors such as beliefs, perseverance and pessimist, these factors may be the reasons 
which affect students to become non resilient students, also these factors might be affecting the responses of the students to the scale, which is used in current research.

According to the second question of the research, (What is the level of meaning of life among Koya University students?). The result showed that, in general, the students have a high level in meaning of life. This finding is consistent with the previous literature results reported by (Mohamad, AbdRazak and Mutiu, 2011) who showed that the postgraduate students perceive life to be meaningful. This may be due that the students started their study on Koya University campus at the beginning of the academic year, that students feel less disappointed in life, they feel more optimistic and hopeful about their lives, also it means that students can clearly understand the meaning of their lives and try to survive. Furthermore, while there are a lot of disappointments and poverty in the current situation of life in our region, students have a high level of meaning of life because most of the Kurdish community is Muslim, believing in God is also one of the important points that affect the achievement of a high level of meaning of life, as well as they are able to find the meaning of life and sense the value of life through being happy and comfortable within their families.

According to third question of the research, (Is there any significant relationship between academic resilience and the meaning of life among Koya University students?). The result showed that there is a significant relationship between them, this result may be related to the relationship between psychological adjustment like (optimism, well-being, and satisfaction with life). The relationship between these two variables means that students have understood life and they are able to overcome the setbacks. These results are consistent with the conclusion of (Panchal, Mukherjee and Kumar, 2016) which indicates that there are positive significances between resilience and optimism among undergraduate students. According to Karaman, Vela and Garcia (2020) there is a positive correlation between meaning of life and hope and life satisfaction, and they found that hope was moderately correlated with resilience and correlated with meaning of life. Al-Tarawneh et al, (2019) found that meaning in life is positively associated with psychological happiness among students at King Khalid University in Abha city in Saudi Arabia. Also, (Rudwan and Alhashimia, 2018) found that there are positive association between resilience and mental health.

According to the fourth question of the research, (Is there prediction of academic resilience based on the meaning of life?). The result showed that the academic resilience predicts the meaning of life, this finding is inconsistent with the previous literature results reported by (Tamannaeifar and Shahmirzaei, 2019) who state that academic resilience can be predicted by other variables such as coping styles and personality traits. Muangi, Ireri and Muaniki (2017) state that the external and internal protective factors jointly predict academic resilience, in addition, internal protective factors had a higher positive and significant predictive value and academic resilience. It may be interpreted that variable academic resilience appropriately predicts meaning of life.

\section{Conclusions}

The aim of this study was to investigate the relationships between academic resilience and the meaning of life among Koya University students. The findings of this study have revealed that the association between students' academic resilience and their meaning of life were statistically significant. In addition, their scores on academic resilience were low, but students have high level of the meaning of life. Furthermore, this study showed that academic resilience predicts meaning of life. 


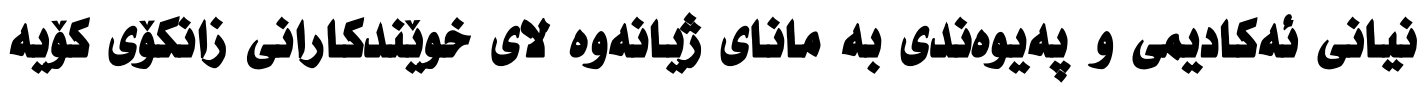

\section{بلهيار ميرزا عزيز}

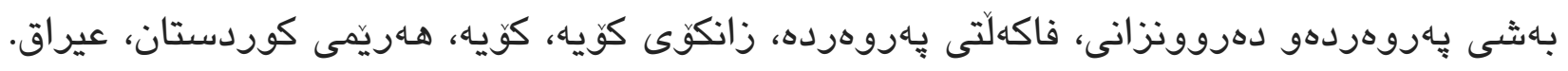
bayar.mirza@koyauniversity.org ئيمهيل

\begin{abstract}
خاليد اسماعيل مصطفى

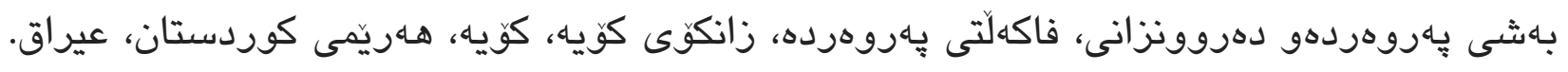

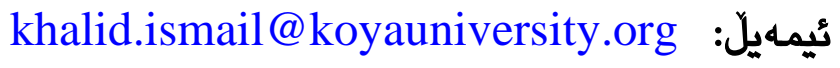

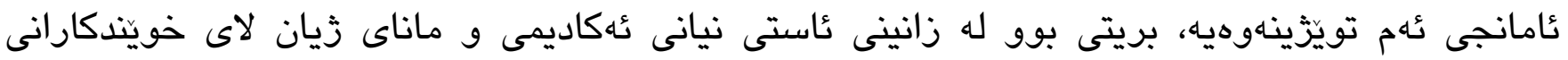

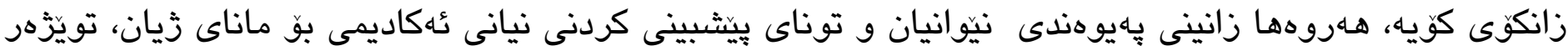

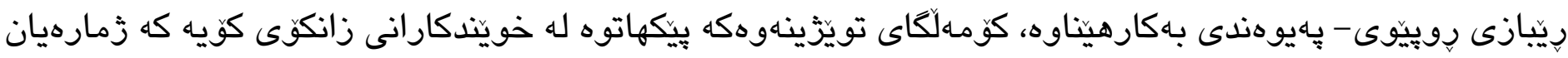

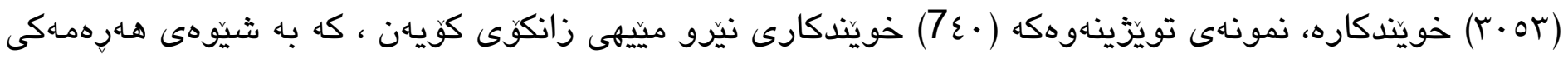

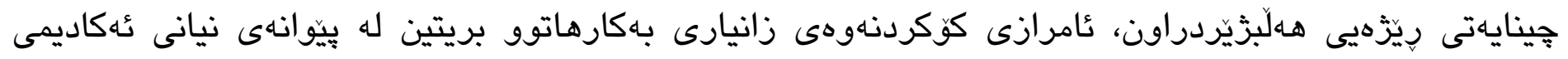

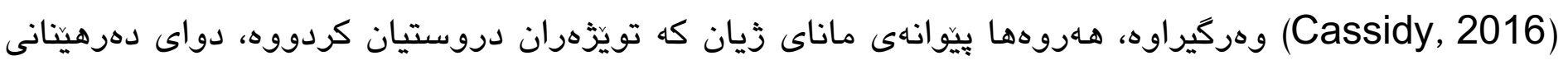

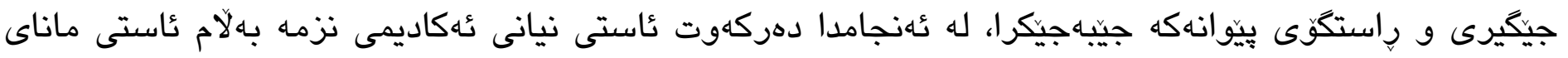

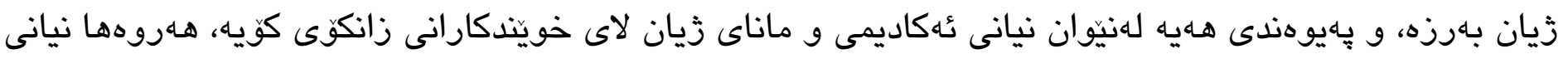

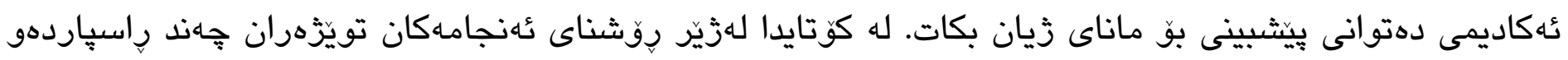

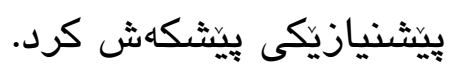

كاليه وشاكان: نيانى ئهكاديمى ، ماناى زيان، خويندكارى زانكو 


\section{References:}

Al-Tarawneh, Z., Baioumy, N., Embong, R., Ab Rahman, R. and Bichi, A.A., 2019. Psychological Happiness and Meaning of Life among Students of King Khalid University Saudi Arabia. Indian Journal of Public Health, 10(09), p.187.

Bajaj, V., Lall, S. S. 2018. 'The Relationship between Identity, Self- Esteem and Meaning in Life among Late Adolescent Women', The International Journal of Indian Psychology, 6(4), pp. 100-119.

Benard, B., 2004. Resiliency: What we have learned. WestEd.

Bronfenbrenner, U., 1979. The ecology of human development: Experiments by nature and design. Harvard university press.

Cabrera, N.L. and Padilla, A.M., 2004. Entering and succeeding in the "culture of college": The story of two Mexican heritage students. Hispanic Journal of Behavioral Sciences, 26(2), pp.152-170.

Cassidy, S., 2016. The Academic Resilience Scale (ARS-30): A new multidimensional construct measure. Frontiers in psychology, 7, p.1787.

Chung, H.F., 2008. Resiliency and character strengths among college students.

Corey, G., 2004. Theory and practice of counseling and psychotherapy. 7th ed. Texas: Thomson Books.

Coşkun, Y.D., Garipağaoğlu, Ç. and Tosun, Ü., 2014. Analysis of the relationship between the resiliency level and problem solving skills of university students. Procedia-Social and Behavioral Sciences, 114, pp.673-680.

Damásio, B.F., Hauck-Filho, N. and Koller, S.H., 2016. Measuring meaning in life: An empirical comparison of two well-known measures. Journal of Happiness Studies, 17(1), pp.431-445.

Frankl, V., 1984. Man's search for meaning. New York: Pocket Books.

Frankl, V.E., 1992. Man's search for meaning: An introduction to logotherapy .(I. Lasch, Trans.) Boston. Beacon Press. Retrieved February, 12, p.2014. 
García-Alandete, J., 2015. Does meaning in life predict psychological well-being?

Grotberg, E.H., 2001. Resilience programs for children in disaster. Ambulatory child health, 7(2), pp.75-83.

Hatice Tambag, R.N. and Rana Can, R.N., 2018. The resilience levels in nursing and health sciences students. International Journal of Caring Sciences, 11(3), pp.1509-1515.

Hedayati, M. A., Khazaei, A, M. (2014) 'An Investigation of the Relationship between Depression, Meaning in Life and Adult Hope, Procedia - Social and Behavioral Sciences, 114(18), pp. 598-601.

Hill, C.E., Kline, K.V., Miller, M., Marks, E., Pinto-Coelho, K. and Zetzer, H., 2018. Development of the Meaning in Life measure. Counselling Psychology Quarterly, 32(2), pp.205-226.

Hobfoll, S.E., 2002. Social and psychological resources and adaptation. Review of general psychology, 6(4), pp.307-324.

Jackson, S.L., 2015. Research methods and statistics: A critical thinking approach. Cengage Learning.

Jensen, P.M., Trollope-Kumar, K., Waters, H. and Everson, J., 2008. Building physician resilience. Canadian Family Physician, 54(5), pp.722-729.

Karaman, M.A., Vela, J.C. and Garcia, C., 2020. Do hope and meaning of life mediate resilience and life satisfaction among Latinx students?. British Journal of Guidance \& Counselling, 48(5), pp.685-696.

Martin, A.J. and Marsh, H.W., 2006. Academic resilience and its psychological and educational correlates: A construct validity approach. Psychology in the Schools, 43(3), pp.267-281.

Mohamad, M., AbdRazak, A. and Mutiu, S., 2011. Meaning in life among muslim students. Procedia-Social and Behavioral Sciences, 30, pp.743-747.

Mwangi, C.N., Ireri, A.M. and Mwaniki, E.W., 2017. Correlates of academic resilience among secondary school students in Kiambu County, Kenya. Interdisciplinary Education and Psychology, 1(1), p.4. 
Mwangi, C.N., Okatcha, F.M., Kinai, T.K. and Ireri, A.M., 2015. Relationship between academic resilience and academic achievement among secondary school students in Kiambu County, Kenya.

Panchal, S., Mukherjee, S. and Kumar, U., 2016. Optimism in relation to well-being, resilience, and perceived stress. International journal of education and psychological research, 5(2), pp.1-6.

Rojas, L.F., 2015. Factors affecting academic resilience in middle school students: A case study. Gist: Education and Learning Research Journal, (11), pp.63-78.

Rudwan, S. and Alhashimia, S., 2018. The Relationship between Resilience \& Mental Health among a Sample of University of Nizwa Students-Sultanate of Oman. European Scientific Journal, 14(2), pp.288-303.

Santhosh, K.R. and James, J., 2013. The effect of resilience on burnout among the blue collared employees in metal factories. International Journal of Multidisciplinary Management Studies, 3(6), pp.48-55.

Scheier, M.F., Wrosch, C., Baum, A., Cohen, S., Martire, L.M., Matthews, K.A., Schulz, R. and Zdaniuk, B., 2006. The life engagement test: Assessing purpose in life. Journal of behavioral medicine, 29(3), p.291.

Schulenberg, S.E., Schnetzer, L.W. and Buchanan, E.M., 2011. The purpose in life test-short form: development and psychometric support. Journal of Happiness Studies, 12(5), pp.861-876.

Shiah, Y.J., Chang, F., Chiang, S.K., Lin, I.M. and Tam, W.C.C., 2015. Religion and health: Anxiety, religiosity, meaning of life and mental health. Journal of religion and health, 54(1), pp.35-45.

Siwek, Z., Oleszkowicz, A. and Słowińska, A., 2017. Values realized in personal strivings and motivation, and meaning in life in polish university students. Journal of Happiness Studies, 18(2), pp.549-573.

Steger, M.F. and Frazier, P., 2005. Meaning in life: One link in the chain from religiousness to wellbeing. Journal of Counseling Psychology, 52(4), p.574.

Steger, M.F., Frazier, P., Oishi, S. and Kaler, M., 2006. The meaning in life questionnaire: Assessing the presence of and search for meaning in life. Journal of counseling psychology, 53(1), p.80. 
Steger, M.F., Kashdan, T.B., Sullivan, B.A. and Lorentz, D., 2008. Understanding the search for meaning in life: Personality, cognitive style, and the dynamic between seeking and experiencing meaning. Journal of personality, 76(2), pp.199-228.

Steger, M.F., Oishi, S. and Kashdan, T.B., 2009. Meaning in life across the life span: Levels and correlates of meaning in life from emerging adulthood to older adulthood. The Journal of Positive Psychology, 4(1), pp.43-52.

Tamannaeifar, M. and Shahmirzaei, S., 2019. Prediction of academic resilience based on coping styles and personality traits. Practice in Clinical Psychology, 7(1), pp.1-10.

Tas, I. and İskender, M., 2018. An Examination of Meaning in Life, Satisfaction with Life, Self-Concept and Locus of Control among Teachers. Journal of education and training studies, 6(1), pp.21-31.

Ursachi, G., Horodnic, I.A. and Zait, A., 2015. How reliable are measurement scales? External factors with indirect influence on reliability estimators. Procedia Economics and Finance, 20, pp.679-686. 